\title{
BENIGN TERTIAN TYPE MALARIAS (P. OVALE AND $P$. VIVAX) CONTRACTED IN AFRICA
}

\author{
ISAO EBISAWA \\ Received March 7 1986/Accepted May 101986
}

\begin{abstract}
Twenty-one cases of ovale malaria were seen among 25 patients of benign tertian malaria contracted during visits to African countries, south of the Sahara. This reflects an increase in the number of Japanese visiting this area as $P$. ovale is, with a few exceptions, endemic only in tropical African countries. Nigeria, Malawi and Guinea were the most frequent countries of infection with 6,4 and 3 cases, respectively.

One patient each with vivax malaria was infected in Malawi, Guinea and Mali; one case was infected in the island country of Madagascar in East Africa.

Because both $P$. ovale and $P$. vivax exist in tropical African countries, we stress the importance of careful examination of blood smears when diagnosing malaria.
\end{abstract}

\section{INTRODUCTION}

The benign tertian malaria parasite most prevalent in tropical Africa is $P$. ovale, which is, with a few exceptions (Jeffery et al., 1954; Wilcox et al., 1954; Jeffery and Young, 1954; Lysenko and Beljaev, 1969) endemic only on this continent (Report of a WHO Scientific Group, 1969; Garnham, 1966).

Japanese patients infected with P. ovale began to appear in 1971 (Amano et al., 1972; Ebisawa $e$ t al., 1972, 1973). The total number of ovale malaria patients seen by the author rose to 21 by the end of 1985, reflecting an increase in the number of Japanese visiting this area.

However, during a review of my case records of malaria patients, 4 cases having been infected with $P$. vivax contracted in tropical Africa came to my attention; obviously both $P$. ovale and $P$. vivax were prevalent in the same tropical African countries.

The purpose of this paper is to report the areas where my patients were infected with $P$. ovale and also to call attention to the fact that both $P$. ovale and $P$. vivax, which is rarely pathogenic to the black people (Jeffery and Young, 1954), are circulating in the same regions.

\section{The Patients and Diagnosis of the Parasite Species}

1) The patients: All patients were Japanese, except for a Dutch national who was infected in Nigeria and developed the illness in Japan. None of the Japanese patients had been in malariaendemic areas during the 5-year period before the onset of the current illness, except in the African countries now under consideration.

Department of Public Health, Toho University School of Medicine, 5-21-16 Omori-nishi, Ohta-ku, Tokyo 143, Japan 
2) Diagnosis: The diagnosis of $P$. ovale was made by paying particular attention to the morphology of the malaria parasites and of the parasite-infected red blood cells. A 1/50 molar phosphate buffer solution of $\mathrm{pH} 7.2-7.4$ was used to make a Giemsa stain throughout the study period. The main criteria of comparison were: smallness of the $P$. ovale parasite in comparison with that of $P$. vivax, the number of merozoites (average number of merozoites in the mature $P$. ovale schizont being 8 ) and incomplete separation of merozoites from each other in the mature $P$. ovale schizonts; larger size and smaller number of Schüffner's dots for $P$. ovale in comparison with those of $P$. vivax-infected red blood cells (Wilcox et al., 1954).

3) The country of infection: This could be pinpointed for patients who had stayed in only one country. However, when the patient had stayed in or travelled through two or more countries, the country of infection was designated simply as "tropical Africa".

\section{RESULTS}

P. ovale: Twenty-one patients were infected with this parasite in countries south of the Sahara (Table 1). Six patients were infected in Nigeria, 4 in Malawi, 3 in Guinea, 2 cases each in Congo (Brazzaville) and Kenya and one in Tanzania. The country of infection in 3 cases was designated as "tropical African countries" as these patients had stayed in more than 3 countries. $P$. vivax: One case each was infected with $P$. vivax in Guinea, Mali and Malawi in sub-Saharan countries and in an island country of Madagascar off the East African coast (Table 1). One patient with vivax malaria who returned to Japan from Kenya could not be confirmed as having been infected there as he had also stayed for some time in India. Two other cases of vivax malaria were infected in Egypt and in Ethiopia, north of the Sahara.

Table 1. Benign tertian malarias infected in Africa (1971-1985)

\begin{tabular}{lcc}
\hline Country & P. ovale & P. vivax \\
\hline North of the Sahara & & 1 \\
$\quad$ Egypt & & 1 \\
Ethiopia & 2 & \\
South of the Sahara & 1 & \\
$\quad$ Kenya & 4 & 1 \\
Tanzania & 3 & 1 \\
Malawi & 6 & 1 \\
Madagascar & & 1 \\
Guinea & 2 & \\
Nigeria & 3 & 6 \\
Mali & 21 & \\
Congo (Brazzaville) & \\
Tropical Africa* & \\
Total &
\end{tabular}

* Applied to patients who stayed in or travelled through more than 3 countries.

A patient of vivax malaria who returned from Kenya was excluded as he had stayed in India within 6 months before the onset of the current illness. 


\section{Discussion}

A high incidence of ovale malaria-about $6 \%$ of all of my malaria patients-is indicative of the increasing number of Japanese visiting countries of tropical Africa, on business, construction works, geographical surverys, pleasure, etc. Until 1977-1978, the majority of my malaria patients were infected in Southeast Asia and Oceania rather than in Africa. But the trends have reversed since 1979 when the number of malaria patients infected on the African continent began to surpass that of the patients infected in Southeast Asia and Oceania combined, even though the latter regions are nearer to Japan (Ebisawa, 1982). This tendency was associated with an increasing number of fatal falciparum malaria cases in my series of patients.

Another indication that Japanese are being exposed more to malaria in African countries was the case of a leukemia patient in Japan who contracted ovale malaria following multiple blood transfusions (Amano et al., 1984).

The fact that vivax malaria was endemic simultaneously with ovale malaria in the tropical African countries of Malawi, Guinea and Mali deserves a short comment. P. vivax is rarely pathogenic to the black population. The circulation of this species of malaria parasite in the tropical African countries may indicate that it was brought to these areas from other continents by other races such as Arabians, Indians, and other people and was picked up by some local anopheline mosquitoes. The presence of $P$. vivax in Madagascar may be easily understood as there exists anthropologically some ethnical relationship between the people of Madagascar and Indonesia where $P$. vivax is endemic. There have been no reports of a simian malaria parasite which can be regarded as an equivalent to the human $P$. vivax on the African continent, in the way that $P$. schwetzi is regarded as an equivalent to the human $P$. ovale (Coatney, 1971).

\section{REFERENCES}

1) Amano, H., Kurata, S. and Yamamoto, T. (1971): On a rare case of ovale malaria, Nettai, 6, 162168 (in Japanese)

2) Amano, S., Ohshima, T., Harano, H., Un, Ko-I, Ito, A., Okubo, T., Watanabe, S. and Mouri, T. (1984): On a case of ovale malaria infected by blood transfusion, Japan. J. Trop. Med. Hyg., 13, 189

3) Coatney, G. R. (1971): Simian malarias in man: facts, implications and predictions, Amer. J. Trop. Med. Hyg., 17, 147-155

4) Ebisawa, I. (1982): Recent problems in malaria, in Oda, T. ed. Seminar in Internal Medicine, INF1, Infectious Diseases, p. 261-271, Nagai Publ. Co., Osaka, Japan (in Japanese)

5) Ebisawa, I. and Komoriya, T. (1972): Case reports of ovale malaria, Naika, 30, 544-546 (in Japanese)

6) Ebisawa, I., Komoriya, T. and Kimura, M. (1973): Study on ovale malaria, J. Japan. Assoc. Infect. Dis., 48, 385-392 (in Japanese)

7) Garnham, P. C. C. (1966): Malaria parasites and other haemosporidia, Blackwell Scientific Publications, Oxford

8) Jeffery, G. M., Young, M. D. and Wilcox, A. (1954): The Donaldson strain of malaria. 1. History and characteristics of the infection, Amer. J. Trop. Med. Hyg., 3, 628-637

9) Jeffery, G. M. and Young, M. D. (1954): The Donaldson strain of malaria. 4. An evaluation and status, Amer. J. Trop. Med. Hyg., 3, 660-664

10) Lysenko, A. J. and Beljaev, A. E. (1969): An analysis of the geographical distribution of Plasmodium ovale, Bull. W. H. O., 40, 383-394 
11) Report of a WHO Scientific Group (1969): Parasitology of malaria, WHO Technical Report Series No. 433 (Geneva)

12) Wilcox, A., Jeffery, G. M. and Young, M. D. (1954): The Donaldson strain of malaria. 2. Morphology of the erythrocytic parasites, Amer. J. Trop. Med. Hyg., 3, 638-649

\section{アフリカ大陸で感染した良性三日熱型マラリア \\ (P. ovale と P. vivax)}

海 老 沢 功

アフリカ大陸で感染した三日熱型マラリア 27 人の内, サハラ砂漠以南の地域で感染した者は $25 人$ で，卵型マラリアは21人であった。卵型マラリア原虫は，少数の例外を除き熱帯アフリカにしか流行 していないので，この事実は熱帯アフリカに旅行，或いは滞在する日本人が多くなった事を示す。卵 型マラリア感染地はナイジェリア，マラウイ，ギニアがそれぞれ $6,4,3$ 人で，その他ケニアとコン ゴ (ブラザビル) が 2 人ずつ, タンザニアが 1 人，西アフリカの 3 つ以上の国に滞在した者が 3 人 あった。

三日熱マラリア患者は，サハラ砂漠以南の地域では，マラウイ，ギニア，マリおよびマダガスカル で 1 人ずつ感染している。サハラ砂漠以北ではエジプトとエチオピアで 1 人ずつ感染している。

特に注目すべき点は，元来黒人にはほとんど病原性がないと言われている三日熱マラリア原虫が, 熱帯アフリカの国で卵型マラリア原虫と同時に流行していることである。熱帯アフリカの三日熱マラ リア原虫は，おそらくアフリカ大陸以外の地域から，アラビア人，インド人，その他の人種によって 持ち込まれたものであろう。マダガスカル島の住民は，インドネシア人と民族学的に近縁であるとい われているので, マダガスカル島に三日熱マラリアがあっても不思議ではない。

熱帯アフリカの国には, 三日熱と卵型マラリアが同時に流行しているので，血液標本は $\mathrm{pH} 7.2-7.4$ の緩衝液を用いて注意深く検査する必要がある。

東邦大学医学部公衆衛生学教室 